\title{
Development and Characterization of Monoclonal Antibodies for the Detection of Fish Protein
}

\author{
Yi-Tien Chen ${ }^{1} \mathbb{D}$ and Yun-Hwa Peggy Hsieh ${ }^{2, *(\mathbb{D})}$ \\ 1 School of Food Safety, Taipei Medical University, Taipei City 110, Taiwan; ytc@tmu.edu.tw \\ 2 Department of Nutrition and Integrative Physiology, Florida State University, Tallahassee, FL 32306, USA \\ * Correspondence: yhsieh@fsu.edu; Tel.: +1-850-524-4456
}

Citation: Chen, Y.-T.; Hsieh, Y.-H.P. Development and Characterization of Monoclonal Antibodies for the Detection of Fish Protein. Foods 2021, 10, 2360. https://doi.org/10.3390/ foods10102360

Academic Editor: Arun K. Bhunia

Received: 2 August 2021

Accepted: 2 October 2021

Published: 4 October 2021

Publisher's Note: MDPI stays neutral with regard to jurisdictional claims in published maps and institutional affiliations.

Copyright: (c) 2021 by the authors. Licensee MDPI, Basel, Switzerland. This article is an open access article distributed under the terms and conditions of the Creative Commons Attribution (CC BY) license (https:// creativecommons.org/licenses/by/ $4.0 /)$.

\begin{abstract}
This study developed and characterized anti-fish monoclonal antibodies (mAbs) capable of detecting fish, a major allergenic food, in processed food products to protect fish sensitized individuals. Of the three mAbs raised against crude protein extract of cooked fish muscle, mAb 8F5 exhibited a positive reaction to all 50 common food fish species tested with no cross-reactions to shellfish, land animals, or food additives. Although the ELISA results were negative against swordfish and yellowfin tuna, western blot clearly detected both after cooking. The $\sim 36 \mathrm{kDa}$ antigenic protein of $\mathrm{mAb} 8 \mathrm{~F} 5$, which was found in all fish species, was detectable by mAb 8F5 in all of the fish samples even after prolonged heat treatment $\left(100{ }^{\circ} \mathrm{C}\right.$, up to $\left.60 \mathrm{~min}\right)$. These findings suggest that $\mathrm{mAb} 8 \mathrm{~F} 5$ has great potential utility as a probe for the immunochemical detection of fish tissue in cooked food.
\end{abstract}

Keywords: fish allergy; monoclonal antibody; muscle protein; thermal-stability; immunoassay; detection

\section{Introduction}

Fish is classified as one of the eight major allergenic foods (fish, shellfish, peanut, soybean, wheat, tree nuts, milk, egg) under the Food Allergen Labeling and Consumer Protection Act (FALCPA) [1], which requires accurate information on food allergens to be included in the label for food products. Labeling fish as a food allergen on food packaging is mandatory in many countries. Surveys suggest that $0.9 \%$ of the population suffers from a fish allergy in the United States, and $0.7 \%$ in European countries [2,3]. About $45 \%$ of children with fish allergy outgrows it in adolescents [4]. However, there is no medical cure for food allergy. Sufferers must therefore strictly avoid any food containing fish to reduce the risk of a severe allergic reaction.

To protect fish-allergic patients, a number of assays have been developed to detect the presence of fish tissue in foods, most of which are protein-based immunoassays or DNA-based polymerase chain reaction (PCR) techniques. While PCR methods require trained personnel and instruments to perform the test and evaluate the data, immunoassays based on highly specific antibody-antigen interactions can be developed into simple and rapid assays such as one-step lateral flow strip tests. Immunoassays are now widely used in clinical, food, industrial, and biological applications targeting specific substances. Parvalbumin, which is generally recognized as the major allergen in fish [5-7], is often used as the marker protein to indicate the presence of fish in foods. Previous reports on the immunoassays developed for this purpose mainly utilize polyclonal antibodies (pAbs) raised against fish parvalbumin. Fæste and Plassen [8] developed a pAb based sandwich ELISA for the detection of fish parvalbumin; however, the assay did not detect all 32 fish samples tested. Shibahara et al. [9] also developed anti-fish parvalbumin pAb, which reacted to sample extracts of all 22 fish species tested, but cross-reacted to cephalopod samples. Their sample extracts were either prepared from heated protein extracts from raw fish samples or from fish powders, so the ability of these assays to detect cooked fish was not verified, even though cooked fish and its products are by far the most common 
for human consumption. A monoclonal antibody (mAb) 3E1 and the antibodies developed by phage display technology have also been developed for the detection of fish parvalbumin $[10,11]$. mAb 3E1 was unable to detect certain fish-species (e.g., pollock, yellowfin tuna and salmon) [10]. The antibodies constructed by phage display were not applied to detect any fish samples [11]. In addition, the amount and thermal stability of parvalbumin varies among fish species [12]. Therefore, those antibodies against parvalbumin do not provide reliable performance in the detection of fish in food products.

Detection methods targeted other fish allergens such as fish collagen [13] and multiple enzymes including creatine kinase (41 kDa) [14], triosephosphate isomerase (26 kDa) [15], glyceraldehyde-phosphate dehydrogenase (38 kDa) [15], enolase (50 kDa) [16], and aldolase $(40 \mathrm{kDa})[16]$ have not been developed to detect the presence of fish tissues in cooked food. Fish collagen degraded after heating and then became weak in allergenicity [13] and these enzymes are not thermally stable, so lose allergenicity after heat treatment. Tropomyosin $(36 \mathrm{kDa})$, a thermal stable muscle protein, was first identified as an allergen in tilapia [17] and later in cod, albacore, and swordfish [18]. However, three commercial fish immunoassay kits against fish parvalbumin or tropomyosin could only achieve a detection rate for 57 bony fish from $26 \%$ to $61 \%$ [19].

In an earlier study, we developed a sandwich enzyme-linked immunosorbent assay (sELISA) using pAbs raised against a mixture of crude protein extracts of cooked fish muscle from ten species (Atlantic salmon, yellowfin tuna, swordfish, black grouper, tilapia, red snapper, amberjack, basa, catfish, and perch) [20]. After cleaning by immunoabsorption, the pAbs recognized a major $36 \mathrm{kDa}$ protein band in the sample protein extract. This $\mathrm{pAb}-$ based sELISA was found to be capable of recognizing all 63 fish species tested, with no cross-reactions with land animals, poultry, or common food additives. Unfortunately, although pAbs are relatively easy and more economic to develop, their specificity and quality are inherently inconsistent from batch to batch. In contrast, a monoclonal antibody $(\mathrm{mAb})$ produced from a single clone of a hybridoma cell has clearly defined characteristics and recognizes only a specific epitope on the antigenic protein. Therefore, in order to provide an effective $\mathrm{mAb}$-based immunochemical method for fish detection, the specific objectives of the present study were to (1) develop fish-specific mAbs raised against crude protein extracts from cooked fish; (2) characterize these mAbs including their selectivity, isotypes, and antigenic proteins; and (3) demonstrate the usefulness of a selected $\mathrm{mAb}$ as a probe in an immunoassay for the detection of fish even after heat treatment.

\section{Materials and Methods}

\subsection{Samples}

The fifty species of fresh or frozen fish samples used in the study were either provided by the State of Florida's Department of Agriculture and Consumer Services or purchased from a reputable seafood distributor. Effort was made to collect as many commonly consumed food fish species as possible including a wide variety of fish species either from domestic waters or of imported commodities. The three shellfish and eleven land animal meat samples were purchased from local food stores. All samples (listed in Table 1) were stored at $-80^{\circ} \mathrm{C}$ until use.

\subsection{Preparation of Protein Extracts}

To prepare protein extracts of the samples, lean muscle tissue from fresh fish, shellfish and land animals of each species was minced individually without cross contamination, and a $5 \mathrm{~g}$ portion of each sample was weighed into a beaker. For the cooked samples, a beaker containing minced raw muscle tissue was covered by aluminum foil and heated in a boiling water bath for $8 \mathrm{~min}$. Twenty five $\mathrm{mL}$ of $0.15 \mathrm{M} \mathrm{NaCl}$ solution was then added to the beakers containing either raw or cooked fish muscle tissue, after which each sample was homogenized for $1 \mathrm{~min}$ at 13,000 rpm using an ULTRA-TURRAX T25 basic homogenizer (IKA Works, Wilmington, NC, USA), held at $4{ }^{\circ} \mathrm{C}$ for $2 \mathrm{~h}$ and then centrifuged $(10,000 \times g$ at $4{ }^{\circ} \mathrm{C}, 30 \mathrm{~min}$ ) and filtered through a Whatman No. 4 filter paper (Whatman, Piscataway, 
NJ, USA). The clear protein filtrates were stored in small vials at $-20{ }^{\circ} \mathrm{C}$ until use. The extracts of four common food additives (porcine gelatin, egg albumin, non-fat dried milk, and soy meal) were prepared as $1 \%(w / v)$ solutions in phosphate buffered saline (PBS) and then extracted in the same manner as the muscle samples. Protein concentrations for each extract were determined using a Protein Assay Kit II (Bio-Rad) according to the manufacturer's protocol using bovine serum albumin (BSA) as the standard. The extracts were stored at $-20^{\circ} \mathrm{C}$ until use.

\subsection{Fish Sample Preparation for Studying the Effect of Heating Times}

To examine the effect of heating time on the immunoreactivity of the mAb with different fish, fresh muscle tissue from three fish species (swordfish, yellowfin tuna, and cod) was cut into cubes $\left(1.5 \mathrm{~cm}^{3}\right)$ of uniform shape and thickness. These pieces were placed in individual small beakers covered with aluminum foil and heated in a boiling water bath for different lengths of time [0 $\mathrm{min}$ (raw), $1 \mathrm{~min}, 3 \mathrm{~min}, 5 \mathrm{~min}, 10 \mathrm{~min}$, and $15 \mathrm{~min}$ ]. The protein concentrations of the protein extracts were determined using a Protein Assay Kit II (Bio-Rad). To investigate the thermal stability of the antigen-antibody binding, muscle tissue cubes of fresh cod were heated in a boiling water bath for different lengths of time [0 min (raw), $5 \mathrm{~min}, 10 \mathrm{~min}, 15 \mathrm{~min}, 20 \mathrm{~min}, 30 \mathrm{~min}, 40 \mathrm{~min}, 50 \mathrm{~min}$, and $60 \mathrm{~min}$ ]. After cooling, five vol. $(v / w)$ of $0.15 \mathrm{M} \mathrm{NaCl}$ solution was added to each and their protein extracts prepared as described above.

\subsection{Development of $m A b s$}

As the main objective of this study was to develop mAbs that specifically targeted only thermal stable fish antigenic proteins, the immunogen was prepared from a crude protein extract of cooked red snapper following the same procedure as that described for the protein samples in the previous section. The cooked fish protein extract was dialyzed (M.W. cut-off of $10 \mathrm{kDa}$ ) in $10 \mathrm{mM}$ PBS for $24 \mathrm{~h}$ and then filtered through a $0.2 \mu \mathrm{m}$ filter. The clear protein filtrate was emulsified with Freund's complete adjuvant as the immunogen. The immunization and the following hybridoma procedures were performed in the Hybridoma Facility at Auburn University, Auburn Alabama in compliance with the University's Animal Welfare guidelines. The details of the subsequent procedures used for the immunization, boosting, hybridoma production, screening, and cloning were as described in [10]. Based on the preliminary screening data, three clones were selected for further study. The Pierce ${ }^{\circledR}$ Rapid ELISA Mouse mAb Isotyping Kit (Thermo Fisher Scientific, USA) was used to determine the isotypes of the selected $\mathrm{mAbs}$ and performed according to the protocol specified by the manufacturer. Properly diluted supernatants were used in this study.

\subsection{Indirect Enzyme-Linked Immunosorbent Assay (iELISA)}

iELISA was used to examine the titers of the mouse sera, positivity of the hybridomas, and the species selectivity of the three selected mAbs. The immunogen and the individual fish protein extracts from 50 fish species, 11 land animal species, three shellfish species, and four food additives (Table 1), together with positive (cooked red snapper extract) and negative (BSA) controls, were each diluted appropriately in $0.06 \mathrm{M}$ carbonate buffer and then $2 \mu \mathrm{g}$ per well coated onto a microplate and held at $37{ }^{\circ} \mathrm{C}$ for $1 \mathrm{~h}$. The wells were washed three times by an ImmunoWash microplate washer (Bio-Rad, Hercules, CA, USA) with PBS containing $0.05 \%$ Tween 20 (PBST) and blocked with blocking solution (1\% BSA in PBS) at $37^{\circ} \mathrm{C}$ for $1 \mathrm{~h}$. The $100 \mu \mathrm{L}$ diluted supernatants (1:5 in PBST with $1 \%$ BSA) of the mAbs were added to the wells and the plate was incubated at $37^{\circ} \mathrm{C}$ for $1 \mathrm{~h}$. After a further washing step, $100 \mu \mathrm{L}$ diluted (1:3000) horseradish peroxidase (HRP)-conjugated goat antimouse immunoglobulin (Ig) G (Sigma-Aldrich, St. Louis, MO, USA) was added and the plate incubated at $37^{\circ} \mathrm{C}$ for another $1 \mathrm{~h}$. The plate was then washed three times and $100 \mu \mathrm{L}$ 2,2-azino-di-[3-ehyl-benothiazoline-6-sulfonic acid] (ABTS) solution added to develop the color at room temperature (RT) for $30 \mathrm{~min}$. The color development was stopped by adding 
$100 \mu \mathrm{L}$ stop solution ( $0.2 \mathrm{M}$ citric acid) per well. The absorbance was measured at $415 \mathrm{~nm}$ using a PowerWave $X$ microplate reader (BioTex, Winooski, VT, USA). The absorbance values for the iELISA were calculated by analyzing two replicates of each sample.

\subsection{Sodium Dodecyl Sulfate Polyacrylamide Gel Electrophoresis (SDS-PAGE) and Western Blot (WB)}

SDS-PAGE was performed according to the standard procedure [21] using 4\% SDSpolyacrylamide stacking gel with $12 \%$ SDS-polyacrylamide separating gel. The sample extracts were mixed with sample buffer (working concentration: $62.5 \mathrm{mM}$ Tris- $\mathrm{HCl}, 2 \%$ SDS, $10 \%$ glycerol, $0.05 \%$ 2-mercaptoethanol, $0.002 \%$ bromophenol blue) and heated in a boiling water bath for $5 \mathrm{~min}$. To characterize the antigenic protein, a fixed volume of protein per lane of raw and cooked fish protein extract was loaded onto the gel. The electrophoresis was performed at $100 \mathrm{~V}$ for $120 \mathrm{~min}$ using Mini-PROTEAN II electrophoresis (Bio-Rad). The polyacrylamide gels were stained with EZ Blue ${ }^{\mathrm{TM}}$ Gel staining (Sigma-Aldrich) according to the manufacturer's instructions.

After the SDS-PAGE was completed, the separated protein bands on the other gel set were transferred onto a nitrocellulose membrane (Bio-Rad) at $300 \mathrm{~mA}$ for $1 \mathrm{~h}$ using Mini Trans-Blot (Bio-Rad) with the transfer buffer (Bio-Rad). The membrane was blocked with 1\% BSA in Tris-buffered saline (TBS). After washing in TBS with $0.05 \%$ Tween-20 (TBST), the membrane was blotted by incubating with the mAbs supernatant diluted 1:5 in TBST with 1\% BSA (antibody buffer) for $1 \mathrm{~h}$ at RT. The excess antibody solution was washed away by TBST and the membrane incubated with goat anti-mouse IgG alkaline phosphatase conjugated antibody (Bio-Rad) diluted 1:3000 in the antibody buffer for $1 \mathrm{~h}$ at RT. The antigenic proteins appeared as dark purple bands after incubating the membrane with BCIP/NBT (Thermo Fisher Scientific) solution for $3 \mathrm{~min}$.

\section{Results and Discussion}

\subsection{Species Selectivity of the Newly Developed mAbs}

A panel of three hybridomas, 2A4, 3F5, and 8F5, was initially selected and cloned based on their strong reactivity with the immunogen. The isotypes of 2A4, 3F5, and 8 F5 were IgG1, IgG2b, and IgG2a, respectively. After expanding the clones, the species selectivity of each was examined against cooked sample extracts of 50 common food fish species, three shellfish, and 11 land animals (Table 1) using iELISA. The overall results are summarized in Table 2. All three of these mAbs showed strong immunoreactivity with most or all of the fish species tested. Although mAb 2A4 and 3F5 did react to cooked samples of all 50 fish species, both also cross reacted with most of the land animal samples, indicating that the epitopes of $\mathrm{mAb} 3 \mathrm{~F} 5$ and 2A4 on their antigenic proteins are located in a conserved region of both fish and land animal species. In contrast, mAb 8F5 reacted strongly with 48 of the 50 cooked fish samples with no cross-reaction with any of the nonfish samples including commonly consumed shellfish, land animals, and food additives. The iELISA results (Table 1) indicate that mAb 8F5 recognizes a conserved region on the amino acid sequence of the antigenic protein that is unique to fish and is not found in any of the representative non-fish species tested.

Table 1. Immunoreactivity of 3 anti-fish mAbs (8F5, 2A4, 3F5) against 50 species of fish, three shellfish, 11 land animals, and four food additives by indirect ELISA.

\begin{tabular}{ccccc}
\hline Market Name & Scientific Name & \multicolumn{3}{c}{ Immunoreactivity $^{\mathbf{a}}$} \\
\hline Fish Species & & mAb 8F5 & mAb 2A4 & mAb 3F5 \\
\hline Cod & Gadus Morhua & +++ & ++ & +++ \\
Orange Roughy & Hoplostethus Atlanticus & +++ & ++ & ++ \\
Striped Bass & Morone Saxatilis & +++ & ++ & +++ \\
Gray Snapper & Lutjanus Griseus & +++ & ++ & +++ \\
\hline
\end{tabular}


Table 1. Cont.

\begin{tabular}{|c|c|c|c|c|}
\hline \multirow{2}{*}{$\begin{array}{c}\text { Market Name } \\
\text { Fish Species }\end{array}$} & \multirow[t]{2}{*}{ Scientific Name } & \multicolumn{3}{|c|}{ Immunoreactivity $^{a}$} \\
\hline & & mAb 8F5 & $\mathrm{mAb} 2 \mathrm{~A} 4$ & mAb 3F5 \\
\hline Black Sea Bass & Centropristis Striata & +++ & ++ & ++ \\
\hline Spotted Seatrout & Cynoscion Nebulosus & +++ & ++ & +++ \\
\hline Lane Snapper & Lutjanus Synagris & +++ & ++ & +++ \\
\hline Mahi-Mahi & Coryphaena Hippurus & +++ & ++ & ++ \\
\hline Cubera Snapper & Lutjanus Cyanopterus & +++ & ++ & +++ \\
\hline Sheephead & Archosargus Probatocephalus & +++ & ++ & +++ \\
\hline Vermilion Snapper & Rhomboplites Aurorubens & +++ & ++ & +++ \\
\hline Yellowtail Snapper & Ocyurus Chrysurus & +++ & ++ & +++ \\
\hline Tra & Pangasius Hypothalmus & ++ & ++ & ++ \\
\hline Red Grouper & Epinephelus Morio & +++ & ++ & +++ \\
\hline Gag Grouper & Mycteroperca Microlepis & +++ & ++ & ++ \\
\hline Tomato Hind & Serranus sonnerati & +++ & +++ & +++ \\
\hline $\begin{array}{c}\text { Orange Spotted } \\
\text { Grouper }\end{array}$ & Epinephelus coioides & +++ & ++ & +++ \\
\hline Atlantic Salmon & Salmo Salar & ++ & ++ & ++ \\
\hline Southern Flounder & Paralichthys Lethostigma & +++ & ++ & +++ \\
\hline Cobia & Rachycentron Canadum & +++ & ++ & +++ \\
\hline Black Grouper & Mycteroperca Bonaci & +++ & ++ & +++ \\
\hline Scamp Grouper & Mycteroperca Phenax & +++ & ++ & +++ \\
\hline Wahoo & Acanthocybium Solandri & + & ++ & ++ \\
\hline Haddock & Melanogrammus Aeglefinus & +++ & ++ & +++ \\
\hline Pollock & P. Pollachius & ++ & ++ & ++ \\
\hline Hog Snapper & Lachnolaimus Maximus & +++ & ++ & +++ \\
\hline Tilapia & Oreochromis Niloticus & +++ & ++ & +++ \\
\hline Red Snapper & Lutjanus Campechanus & +++ & ++ & ++ \\
\hline Pompano & Trachinotus Carolinus & +++ & ++ & +++ \\
\hline Mullet & Mugil Gyrans & +++ & ++ & +++ \\
\hline Yellow Edge Grouper & Variola Louti & +++ & ++ & +++ \\
\hline Alaskan Halibut & Hippoglossus Stenolepsis & +++ & ++ & +++ \\
\hline Rainbow Trout & Oncorhynchus mykiss & +++ & ++ & +++ \\
\hline Catfish & Ictalurus punctatus & +++ & ++ & +++ \\
\hline Bluegill & Lepomis macrochirus & +++ & ++ & +++ \\
\hline Chinook salmon & Oncorhynchus tshawytscha & +++ & ++ & +++ \\
\hline Ocean Perch & Sebastes alutus & +++ & ++ & +++ \\
\hline Mangrove Snapper & Lutjanus griseus & ++ & ++ & +++ \\
\hline Whiting & Menticirrhus littoralis & ++ & ++ & ++ \\
\hline Basa & Pangasius bocourti, & +++ & +++ & +++ \\
\hline Camouflage Grouper & Epinephelus polyphekadion & +++ & +++ & +++ \\
\hline Coral Trout & Plectropomus leopardus & +++ & +++ & +++ \\
\hline Dusky Grouper & Epinephelus marginatus & +++ & +++ & +++ \\
\hline Redmouth Grouper & Aethaloperca rogaa & +++ & +++ & +++ \\
\hline Squaretail Grouper & Plectropomus areolatus & +++ & ++ & +++ \\
\hline Trout Cod & Maccullochella macquariensis & +++ & +++ & +++ \\
\hline Wavy Lined Grouper & Epinephelus undulosus & +++ & ++ & +++ \\
\hline $\begin{array}{l}\text { Caribbean Red } \\
\text { Snapper }\end{array}$ & Lutjanus purpureus & +++ & ++ & ++ \\
\hline Yellowfin Tuna & Thunnus Albacares & - & ++ & ++ \\
\hline Swordfish & Xiphias Gladius & - & + & + \\
\hline \multicolumn{5}{|c|}{ Non-Fish Species } \\
\hline White Shrimp & Litopenaeus setiferus & - & - & - \\
\hline Blue Crab & Callinectes sapidus & - & - & - \\
\hline Scallop & Pectinidae & - & - & - \\
\hline Chicken & Gallus Domesticus & - & + & - \\
\hline Turkey & Meleagris & - & ++ & ++ \\
\hline
\end{tabular}


Table 1. Cont.

\begin{tabular}{ccccc}
\hline Market Name & Scientific Name & \multicolumn{3}{c}{ Immunoreactivity $^{\mathbf{a}}$} \\
\hline Fish Species & & mAb 8F5 & mAb 2A4 & mAb 3F5 \\
\hline Pork & Sus Scrofa Domesticus & - & ++ & ++ \\
Beef & Bos Primigenius & - & ++ & ++ \\
Lamb & Ovis Aries & - & + & - \\
Rabbit & Oryctolagus Cuniculus & - & ++ & ++ \\
Horse & Equus Ferus Caballus & - & ++ & ++ \\
Deer & Cervidae & - & ++ & ++ \\
Elk & Cervus canadensis & - & ++ & ++ \\
Rat & Rattus & - & ++ & +++ \\
Frog & Lithobates catesbeianus & - & ++ & +++ \\
\hline
\end{tabular}

\begin{tabular}{|c|c|c|c|}
\hline \multicolumn{4}{|c|}{ Food Additives } \\
\hline Gelatin & - & - & - \\
\hline Egg albumin & - & - & - \\
\hline Soy protein & - & - & - \\
\hline Nonfat Dried Milk & - & - & - \\
\hline
\end{tabular}

Table 2. Isotypes, antigenic proteins, and summarized iELISA results against 50 species of fish, three shellfish, 11 land animals, and four food additives of the three anti-fish mAbs.

\begin{tabular}{|c|c|c|c|c|c|c|c|c|c|c|}
\hline \multirow{3}{*}{$\mathrm{mAb}$} & \multirow{3}{*}{ Isotype } & \multirow{3}{*}{$\begin{array}{c}\text { Antigenic } \\
\text { Protein (kDa) }{ }^{a}\end{array}$} & \multicolumn{8}{|c|}{ Immunoreactivity against } \\
\hline & & & \multicolumn{2}{|c|}{50 Fish Species } & \multicolumn{2}{|c|}{3 Shellfish Species } & \multicolumn{2}{|c|}{11 Land Animal Species } & \multicolumn{2}{|c|}{4 Food Additives } \\
\hline & & & Positive & Negative & Positive & Negative & Positive & Negative & Positive & Negative \\
\hline $8 \mathrm{~F} 5$ & $\operatorname{IgG} 2 \mathrm{a}$ & 36 & 48 & $\begin{array}{c}2 \\
\text { (swordfish } \\
\text { and yellowfin } \\
\text { tuna) }\end{array}$ & 0 & 3 & 0 & 11 & 0 & 4 \\
\hline $2 \mathrm{~A} 4$ & IgG1 & 36 & 50 & 0 & 0 & 3 & 11 & 0 & 0 & 4 \\
\hline $3 \mathrm{~F} 5$ & $\mathrm{IgG} 2 \mathrm{~b}$ & 36 & 50 & 0 & 0 & 3 & 9 & 2 & 0 & 4 \\
\hline
\end{tabular}

The iELISA absorbance threshold for a qualitative determination of the positive/ negative results in this study was set at $\mathrm{OD}=0.2$; this value is widely used as the cut-off by many analytical, biological, and medical researchers [22,23]. An OD value below 0.2 is the detection limit for visual inspection and is therefore generally recognized as negative in commercial immunoassay kits. In this study, only two fish samples, swordfish and yellowfin tuna, produced very weak reaction signals with mAb 8F5 and were thus initially classed as negative samples. Further investigations explored the reasons for this weak or lack of reaction of these two species with $\mathrm{mAb} 8 \mathrm{~F} 5$.

\subsection{Antigenic Components Recognized by the Newly Developed mAbs}

Randomly selected fish species from positively reacting fish samples were used to examine the antigenic protein components of the three new mAbs, 2A4, 3F5, and $8 \mathrm{~F} 5$ by WB. Interestingly, this revealed that all three $\mathrm{mAbs}$ recognized a $36 \mathrm{kDa}$ antigenic protein band (Table 2 and Figure S1). Due to the substantial cross-reactivity with land animal proteins exhibited by mAbs 2A4 and 3F5, they are not useful for specific fish detection. Therefore, only the fish-specific $\mathrm{mAb} 8 \mathrm{~F} 5$ was selected for further investigation in this study. While WB results for mAb 2A4 and 3F5 are attached in the Supplementary Materials as Figure S1, the SDS-PAGE protein profile for the extracts of the eight species (cod, snapper, salmon, grouper, pompano, mullet, tilapia, and catfish) of cooked fish $\left(100{ }^{\circ} \mathrm{C}\right.$ for $\left.8 \mathrm{~min}\right)$ and the antigenic protein bands revealed by WB using $\mathrm{mAb} 8 \mathrm{~F} 5$ are shown in Figure 1. 
WB revealed that this $36 \mathrm{kDa}$ protein is the antigenic protein consistently recognized by $\mathrm{mAb} 8 \mathrm{~F} 5$ in all of these fish species (Figure 1b), although the molecular weight of this antigenic protein in salmon is slightly heavier than that in the other species. These results confirm that the $36 \mathrm{kDa}$ protein is the major thermal stable protein appearing in all the fish samples, and it is also the antigen for the mAb 8F5. These suggest that this $\mathrm{mAb}$ recognizes a unique fish conserved region on the protein sequence of this $36 \mathrm{kDa}$ protein. The pAb reagent used in the previously reported sELISA, which successfully detected all 63 fish species tested, also recognized a major $36 \mathrm{kDa}$ protein band in all the cooked fish samples [20]. The $36 \mathrm{kDa}$ protein recognized by mAb $8 F 5$ and pAb could be the same antigenic protein because their immunogens were similarly prepared in our laboratory.
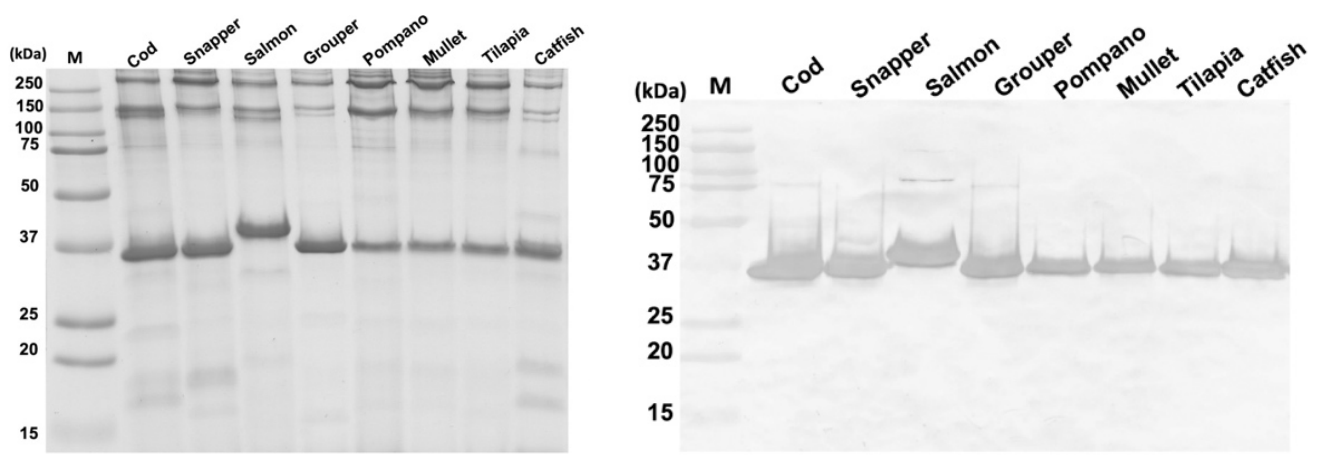

(a)

(b)

Figure 1. SDS-PAGE (a) and western blot analysis (b) of cooked fish samples using mAb 8F5 supernatant (1:5). The amount of sample loaded on the $12 \%$ SDS-PAGE was $6 \mu \mathrm{L}$ per lane. M: molecular weight marker.

\subsection{Antigenic Protein Profile of Yellowfin Tuna and Swordfish}

The 8 min cooked yellowfin tuna and swordfish exhibited either very weak or negative immunoreactivity (OD < 0.2) with mAb 8F5 in iELISA (Table 1). In order to investigate and ensure that $\mathrm{mAb} 8 \mathrm{~F} 5$ has the capability to detect all the fish species tested, the immunoreactivity of yellowfin tuna and swordfish were further studied using WB to examine whether heat treatment affected their antigen exposure, thus the immunoreactivity against $\mathrm{mAb} 8 \mathrm{F5}$. As noticed during the protein extraction step performed for this analysis, the extracted protein concentration of these two fish species decreased much faster after heating compared with the other fish samples, which is why the soluble protein concentrations extracted from these two fish species heated for shorter times $(0 \mathrm{~min}, 1 \mathrm{~min}, 3 \mathrm{~min}, 5 \mathrm{~min}$, $10 \mathrm{~min}$, and $15 \mathrm{~min}$ ) than the other samples were examined (Table 3). A cod sample was included in the analysis as the positive control for comparison. The results show that the soluble protein concentrations in the extracts of raw swordfish and yellowfin tuna were $8.73 \mathrm{mg} / \mathrm{mL}$ and $16.09 \mathrm{mg} / \mathrm{mL}, 2.3$ to 4.2 times higher, respectively, than that of raw cod $(3.83 \mathrm{mg} / \mathrm{mL})$. The protein concentration of all three fish samples decreased dramatically after just $1 \mathrm{~min}$ to $5 \mathrm{~min}$ of heating. After $15 \mathrm{~min}$ of heating, the protein concentrations of swordfish $(0.31 \mathrm{mg} / \mathrm{mL})$ and yellowfin tuna $(0.29 \mathrm{mg} / \mathrm{mL})$ were far below that of cod $(1.17 \mathrm{mg} / \mathrm{mL})$, indicating that the muscle protein of these two species is considerably more heat-labile than the other mAb 8F5 positive species such as cod. The thermal stability of muscle protein is thought to be different for different fish species due to the ambient temperature of their habitat and the style of swimming the fish typically engage in [24-26]. The unusual characteristics in the heat stability of the muscle proteins of yellowfin tuna and swordfish may be due to the way they move between different ambient temperature zones and their particular exercise style. 
Table 3. Changes in soluble protein concentrations of fish samples (yellowfin tuna, swordfish, cod) with different heating times (0-15 $\mathrm{min})$.

\begin{tabular}{ccccccc}
\hline \multirow{2}{*}{$\begin{array}{c}\text { Heating } \\
\text { Time }\end{array}$} & $\begin{array}{c}\text { Concentration } \\
(\mathbf{m g} / \mathbf{m L})^{\mathbf{a}}\end{array}$ & $\begin{array}{c}\text { Ratio of } \\
\text { Concentration }(\%)\end{array}$ & $\begin{array}{c}\text { Concentration } \\
(\mathbf{m g} / \mathbf{m L})^{\mathbf{a}}\end{array}$ & $\begin{array}{c}\text { Ratio of } \\
\text { Concentration }(\mathbf{\%})\end{array}$ & $\begin{array}{c}\text { Concentration } \\
(\mathbf{m g} / \mathbf{m L})\end{array}$ & $\begin{array}{c}\text { a } \\
\text { Cotio of } \\
\text { Concentration }(\mathbf{\%})\end{array}$ \\
\hline $0 \mathrm{~min}$ & $16.09 \pm 0.64$ & 100 & $8.73 \pm 0.23$ & 100 & $3.83 \pm 0.09$ & 100 \\
\hline $1 \mathrm{~min}$ & $12.67 \pm 0.13$ & 78.7 & $7.69 \pm 0.12$ & 88.1 & $3.72 \pm 0.08$ & 97.1 \\
\hline $3 \mathrm{~min}$ & $6.00 \pm 0.11$ & 37.3 & $3.70 \pm 0.06$ & 42.4 & $1.78 \pm 0.04$ & 46.4 \\
\hline $5 \mathrm{~min}$ & $0.16 \pm 0.02$ & 1 & $0.30 \pm 0.03$ & 3.4 & $1.09 \pm 0.04$ & 28.5 \\
\hline $10 \mathrm{~min}$ & $0.17 \pm 0.01$ & 1.1 & $0.27 \pm 0.01$ & 3.1 & $1.04 \pm 0.03$ & 27.2 \\
\hline $15 \mathrm{~min}$ & $0.29 \pm 0.02$ & 1.8 & $0.31 \pm 0.01$ & 3.6 & $1.17 \pm 0.01$ & 30.5 \\
\hline
\end{tabular}

We then examined the effect of heating time (from 0 to $15 \mathrm{~min}$ ) on the immunoreactivity of the antigenic protein with $\mathrm{mAb} 8 \mathrm{~F} 5$ using WB. The SDS-PAGE images (Figure 2a-c) and the combined WB results (Figure $2 \mathrm{~d}$ ) closely matched the observations regarding the difference in the amount of the total soluble proteins and the $36 \mathrm{kDa}$ antigenic protein, respectively, in different fish species with different heating periods. In SDS-PAGE gels, multiple protein bands appeared in raw and 1-min cooked samples, but gradually decreased to only a few bands after $5 \mathrm{~min}$ of heating (Figure $2 \mathrm{a}-\mathrm{c}$ ). The $36 \mathrm{kDa}$ band seems to appear in the SDS-PAGE gels of both raw and cooked fish samples. No or very weak antigenic bands were observed in yellowfin tuna and swordfish in raw and cooked fish below five minutes, however, the $36 \mathrm{kDa}$ protein band appeared from 5-min of cooking onward. Compared to the cod samples (cooked for $5 \mathrm{~min}$ to $15 \mathrm{~min}$ ), the antigenic protein bands of yellowfin tuna and swordfish were much weaker. This experiment loaded a fixed volume $(6 \mu \mathrm{L}$ per lane) of protein extracts on the gel to examine any changes in the amount of the antigen in the fish extracts for different heating times. Even though these two species contain much higher amounts of total soluble proteins than cod in raw tissue, heating quickly denatures and insolubilizes most of these proteins and the thermal stable $36 \mathrm{kDa}$ protein remains in the extract at an increased proportion related to the other proteins. For less than $15 \mathrm{~min}$ of cooking time, the longer the heating, the stronger the antigenic band appeared in all three species, suggesting more hidden epitopes were gradually exposed as this peptide chain unfolded upon heating.

Although yellowfin tuna and swordfish produced negative iELISA results, WB revealed that $\mathrm{mAb} 8 \mathrm{~F} 5$ does indeed react with these two fish species, targeting the same antigen. The weak iELISA signals for yellowfin tuna and swordfish are likely due to the low antigen concentration in their muscles and the relatively small amount of protein adsorbed on each well. A higher concentration with longer heat treatment is required to reveal the immunoreactivity of this group of fish species. 


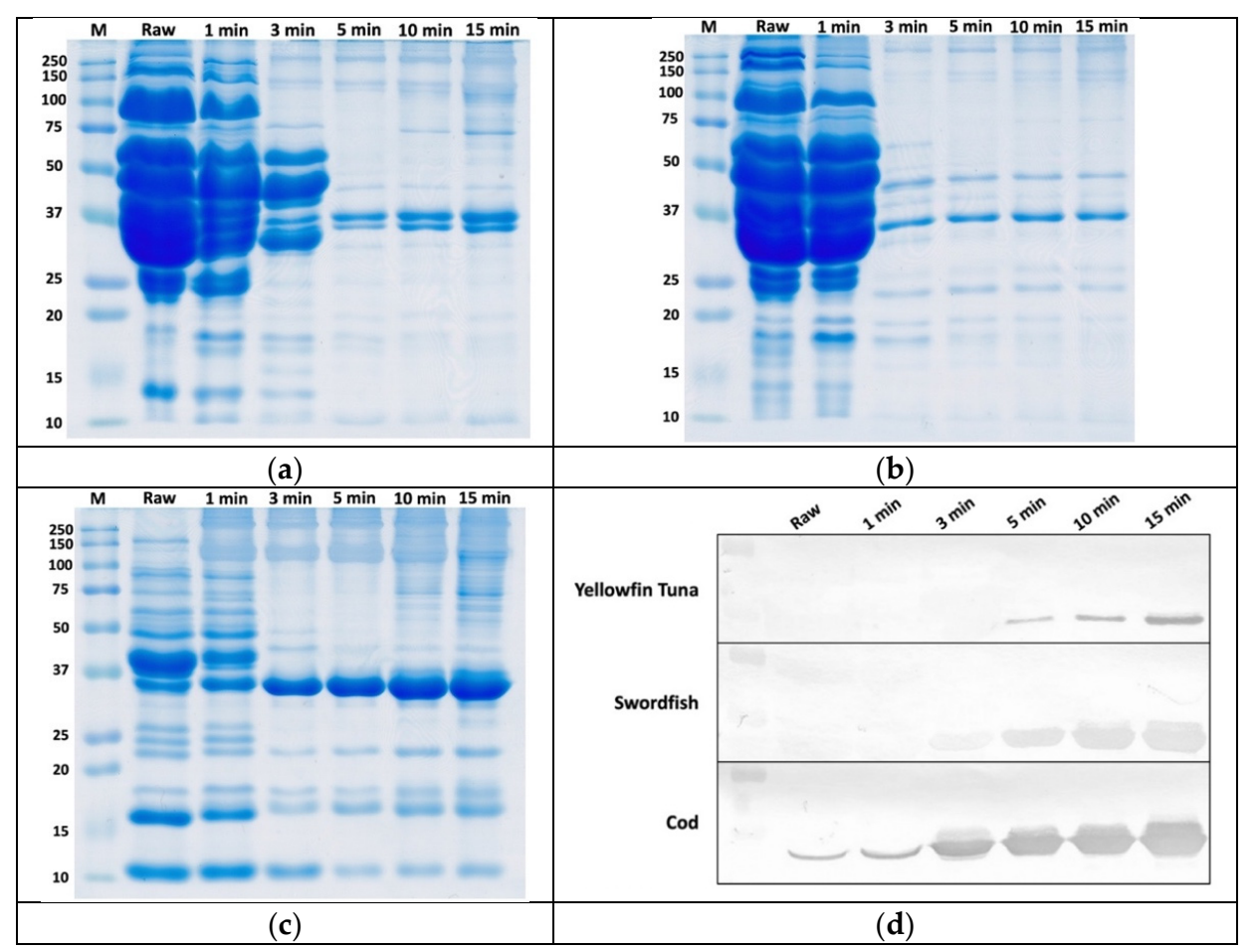

Figure 2. SDS-PAGE gel images (a-c) and western blot antigenic protein profiles using mAb 8F5 supernatant (1:5), (d) of yellowfin tuna, swordfish, and cod cooked for different lengths of time. The sample loading was $6 \mu \mathrm{L}$ per lane. M: Molecular weight marker.

\subsection{Thermal Stability of the $m A B$ 8F5 Epitope}

Heating is the most commonly used processing method for fish before consumption. Most muscle proteins are sensitive to heat and become denatured after heating. The configuration of the epitope on the antigenic protein can be impeded by heating, affecting the immunoreactivity due to the obstructed antibody-antigen binding [27-29]. The thermal stability of the epitope is thus a critical factor for the immunoreactivity and, hence, the detectability of the antigenic protein. To ensure detectability in fish samples that have undergone lengthy heating times, we also investigated the effect of heating time (up to $60 \mathrm{~min}$ ) on the thermal stability of the epitope on the $36 \mathrm{kDa}$ antigenic protein with $\mathrm{mAb}$ 8F5. Cod was selected as a representative species because it exhibited similarly strong iELISA signals as the majority of other positive species tested and is one of the top ten seafood species consumed worldwide [30]. The SDS-PAGE and WB results are presented in Figure $3 a, b$, respectively. More proteins $(15 \mu \mathrm{L})$ were loaded on each lane of the gel in this experiment than the previous one $(6 \mu \mathrm{L})$ in order to observe the change in immunoreactivity of the fish over this wide range of heating times (from 5 to $60 \mathrm{~min}$ ), which is why the overall color intensity of the protein bands in this figure appeared darker than those shown in Figures 1 and 2. The SDS-PAGE profile revealed that the $36 \mathrm{kDa}$ antigenic protein did indeed retain its integrity for up to $60 \mathrm{~min}$ of heating time, with only a slight decrease in the color intensity of the bands after $30 \mathrm{~min}$ of heating (Figure 3a). The WB results showed a total of three antigenic bands on the membrane; in addition to the main $36 \mathrm{kDa}$ protein, there were two minor protein bands at around $75 \mathrm{kDa}$ and $100 \mathrm{kDa}$. The intensities of all three decreased after $30 \mathrm{~min}$ of heating (Figure 3b), indicating that excessive or prolonged heating gradually and damages the epitope to some extent. It is likely that the $75 \mathrm{kDa}$ and $100 \mathrm{kDa}$ bands are the dimers and trimers of the $36 \mathrm{kDa}$ antigenic protein because they also bind to $\mathrm{mAb} 8 \mathrm{~F} 5$. These results suggest that the epitope of mAb $8 \mathrm{~F} 5$ is highly thermally stable even after prolonged heating in boiling water for up to $60 \mathrm{~min}$, suggesting that $\mathrm{mAb}$ $8 \mathrm{~F} 5$ can be used for the detection of fish in products that have been cooked for a wide range of cooking times. 
The $\mathrm{pAb}$ previously used in the sELISA apparently recognized the same major $36 \mathrm{kDa}$ protein in all 63 cooked fish samples tested [20]. This supports our contention that this protein is not only highly antigenic, but also ubiquitously present in all common food fish species with fish-specific epitopes, making it an ideal biomarker for the immunodetection of fish. Therefore, it is important to further investigate the identity of the $36 \mathrm{kDa}$ protein. Based on its thermal stability and molecular weight, the $36 \mathrm{kDa}$ antigen is likely to be fish tropomyosin. The identification and characterization of this $36 \mathrm{kDa}$ protein has been performed and the findings will be reported separately.

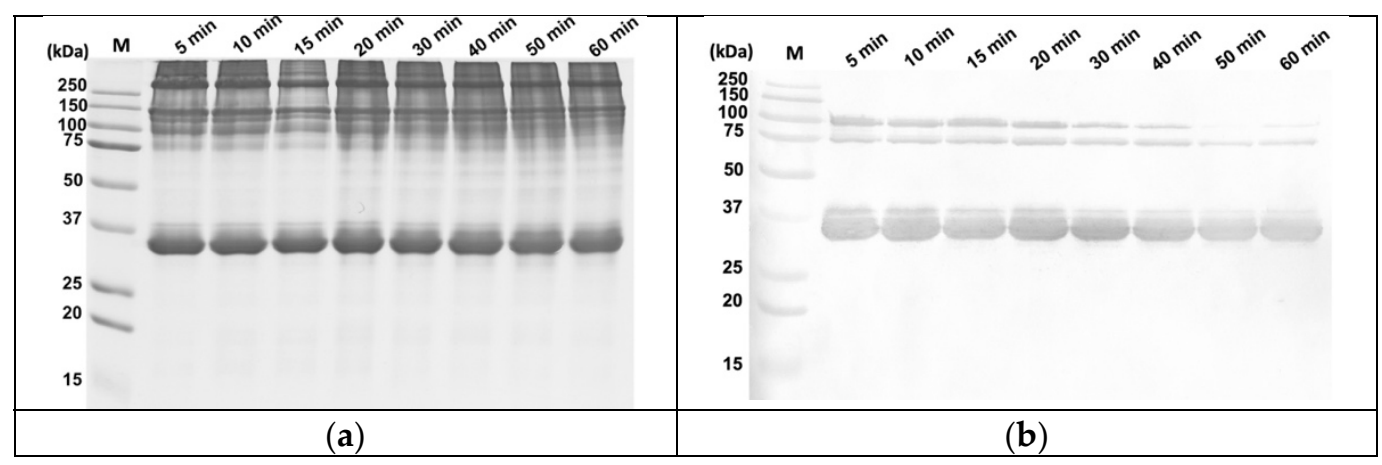

Figure 3. SDS-PAGE (a) and western blot analysis (b) of cooked cod treated for different heating times using mAb 8F5 supernatant (1:5). The amount of sample loaded on the $12 \%$ SDS-PAGE was $15 \mu \mathrm{L}$ per lane. M: molecular weight marker.

\section{Conclusions}

In this study, we developed a fish-specific mAb, 8F5, that cross-reacts with all 50 common food fish species tested without exhibiting any cross-reactions with the 18 shellfish, land animals, or food additives tested. The $36 \mathrm{kDa}$ antigenic protein of $\mathrm{mAb} 8 \mathrm{~F} 5$ that appears in both raw and cooked fish of all species is a thermally stable muscle protein common to all the fish species tested; the binding was thermally stable up to $60 \mathrm{~min}$ of heat treatment at $100{ }^{\circ} \mathrm{C}$. Characterization of this $36 \mathrm{kDa}$ protein is of great interest and importance as it has the potential to serve as an excellent fish marker protein. The high thermal stability and fish-selectivity of the epitope recognized by mAb $8 \mathrm{~F} 5$ demonstrate the potential utility of this $\mathrm{mAb}$ in the future development of various forms of immunoassays for the specific detection of fish in cooked foods. The real utility must be assured by a complete validation, performed with the analysis of real commercial and complex food samples, especially, those indicating in the label that "may contain" or do-not-contain fish, where the concentration of this protein can be very low or is being hidden by the food matrix, which would really assure consumer protection.

Supplementary Materials: The following are available online at https:/ / www.mdpi.com/article/10 .3390 / foods10102360/s1, Figure S1: Western blot analysis of cooked fish samples using mAb 2A4 (a) and mAb 3F5 (b) supernatant (1:5), respectively.

Author Contributions: Conceptualization, Y.-H.P.H.; Methodology, Y.-T.C.; Validation, Y.-T.C.; Formal analysis, Y.-T.C.; Resources, Y.-H.P.H.; Data curation, Y.-T.C.; Writing—original draft preparation, Y.-T.C.; Writing—review and editing, Y.-H.P.H.; Supervision, Y.-H.P.H.; Project administration, Y.H.P.H.; Funding acquisition, Y.-H.P.H. All authors have read and agreed to the published version of the manuscript.

Funding: This research was funded by the U.S. Department of Agriculture NRI/AFRI grant (grant number 2009-35503-051850).

Institutional Review Board Statement: Not applicable.

Informed Consent Statement: Not applicable.

Data Availability Statement: Not applicable. 
Conflicts of Interest: The authors declare no conflict of interest.

\section{References}

1. Food and Drug Administration (FDA). Food Allergen Labeling and Consumer Protection Act of 2004 (Public Law 108-282). Available online: http:/ / www.fda.gov/downloads/Food/GuidanceRegulation/UCM179394.pdf (accessed on 21 July 2021).

2. Burney, P.; Summers, C.; Chinn, S.; Hooper, R.; Ree, R.V.; Lidholm, J. Prevalence and Distribution of Sensitization to Foods in the European Community Respiratory Health Survey: A EuroPrevall Analysis. Allergy 2010, 65, 1182-1188. [CrossRef]

3. Gupta, R.S.; Warren, C.M.; Smith, B.M.; Jiang, J.; Blumenstock, J.A.; Davis, M.M.; Schleimer, R.P.; Nadeau, K.C. Prevalence and Severity of Food Allergies among US Adults. JAMA Netw. Open 2019, 2, e185630. [CrossRef]

4. Xepapadaki, P.; Christopoulou, G.; Stavroulakis, G.; Freidl, R.; Linhart, B.; Zuidmeer, L.; Lakoumentas, J.; van Ree, R.; Valenta, R.; Papadopoulos, N.G. Natural History of IgE-Mediated Fish Allergy in Children. J. Allergy Clin. Immunol. Pract. 2021, 9 , 3147-3156.e5. [CrossRef] [PubMed]

5. Elsayed, S.; Aas, K. Characterization of a Major Allergen (Cod) Observations on Effect of Denaturation on the Allergenic Activity. J. Allergy Clin. Immun. 1971, 47, 283-291. [CrossRef]

6. Matricardi, P.M.; Kleine-Tebbe, J.; Hoffmann, H.J.; Valenta, R.; Hilger, C.; Hofmaier, S.; Aalberse, R.C.; Agache, I.; Asero, R.; Ballmer-Weber, B.; et al. EAACI Molecular Allergology User's Guide. Pediatr. Allergy Immu. 2016, 27, 1-250. [CrossRef] [PubMed]

7. Sørensen, M.; Kuehn, A.; Mills, E.N.C.; Costello, C.A.; Ollert, M.; Småbrekke, L.; Primicerio, R.; Wickman, M.; Klingenberg, C. Cross-Reactivity in Fish Allergy: A Double-Blind, Placebo-Controlled Food-Challenge Trial. J. Allergy Clin. Immun. 2017, 140, 1170-1172. [CrossRef] [PubMed]

8. Fæste, C.K.; Plassen, C. Quantitative Sandwich ELISA for the Determination of Fish in Foods. J. Immunol. Methods 2008, 329, 45-55. [CrossRef] [PubMed]

9. Shibahara, Y.; Uesaka, Y.; Wang, J.; Yamada, S.; Shiomi, K. A Sensitive Enzyme-Linked Immunosorbent Assay for the Determination of Fish Protein in Processed Foods. Food Chem. 2013, 136, 675-681. [CrossRef]

10. Gajewski, K.G.; Hsieh, Y.-H.P. Monoclonal Antibody Specific to a Major Fish Allergen: Parvalbumin. J. Food. Protect. 2009, 72, 818-825. [CrossRef]

11. Bublin, M.; Kostadinova, M.; Fuchs, J.E.; Ackerbauer, D.; Moraes, A.H.; Almeida, F.C.L.; Lengger, N.; Hafner, C.; Ebner, C.; Radauer, C.; et al. A Cross-Reactive Human Single-Chain Antibody for Detection of Major Fish Allergens, Parvalbumins, and Identification of a Major IgE-Binding Epitope. PLoS ONE 2015, 10, e0142625. [CrossRef]

12. Saptarshi, S.R.; Sharp, M.F.; Kamath, S.D.; Lopata, A.L. Antibody Reactivity to the Major Fish Allergen Parvalbumin Is Determined by Isoforms and Impact of Thermal Processing. Food Chem. 2014, 148, 321-328. [CrossRef] [PubMed]

13. Hamada, Y.; Nagashima, Y.; Shiomi, K. Identification of Collagen as a New Fish Allergen. Biosci. Biotechnol. Biochem. 2001, 65, 285-291. [CrossRef]

14. Liu, R.; Krishnan, H.B.; Xue, W.; Liu, C. Characterization of Allergens Isolated from the Freshwater Fish Blunt Snout Bream (Megalobrama Amblycephala). J. Agric. Food Chem. 2011, 59, 458-463. [CrossRef]

15. González-Mancebo, E.; Gandolfo-Cano, M.; González-de-Olano, D.; Mohedano-Vicente, E.; Bartolome, B.; Pastor-Vargas, C. Identification of a Novel Protein Allergen in Mediterranean Silverside Fish Species. Ann. Allergy Asthma. Immunol. 2014, 113, 114-115. [CrossRef] [PubMed]

16. Kuehn, A.; Hilger, C.; Lehners-Weber, C.; Codreanu-Morel, F.; Morisset, M.; Metz-Favre, C.; Pauli, G.; Blay, F.; Revets, D.; Muller, C.P.; et al. Identification of Enolases and Aldolases as Important Fish Allergens in Cod, Salmon and Tuna: Component Resolved Diagnosis Using Parvalbumin and the New Allergens. Clin. Exp. Allergy 2013, 43, 811-822. [CrossRef]

17. Liu, R.; Holck, A.L.; Yang, E.; Liu, C.; Xue, W. Tropomyosin from Tilapia (Oreochromis Mossambicus) as an Allergen. Clin. Exp. Allergy 2013, 43, 365-377. [CrossRef]

18. González-Fernández, J.; Alguacil-Guillén, M.; Cuéllar, C.; Daschner, A. Possible Allergenic Role of Tropomyosin in Patients with Adverse Reactions after Fish Intake. Immunol. Investig. 2018, 47, 1-14. [CrossRef] [PubMed]

19. Ruethers, T.; Taki, A.C.; Khangurha, J.; Roberts, J.; Buddhadasa, S.; Clarke, D.; Hedges, C.E.; Campbell, D.E.; Kamath, S.D.; Lopata, A.L.; et al. Commercial Fish ELISA Kits Have a Limited Capacity to Detect Different Fish Species and Their Products. J. Sci. Food Agric. 2020, 100, 4353-4363. [CrossRef]

20. Chen, Y.-T.; Hsieh, Y.-H.P. A Sandwich ELISA for the Detection of Fish and Fish Products. Food Control. 2014, 40, 265-273 [CrossRef]

21. Laemmli, U.K. Cleavage of Structural Proteins during the Assembly of the Head of Bacteriophage T4. Nature 1970, 227, 680-685. [CrossRef]

22. Güven, E.; Duus, K.; Lydolph, M.C.; Jørgensen, C.S.; Laursen, I.; Houen, G. Non-Specific Binding in Solid Phase Immunoassays for Autoantibodies Correlates with Inflammation Markers. J. Immunol. Methods 2014, 403, 26-36. [CrossRef]

23. Hartman, H.; Wang, Y.; Schroeder, H.W.; Cui, X. Absorbance Summation: A Novel Approach for Analyzing High-Throughput ELISA Data in the Absence of a Standard. PLOS ONE 2018, 13, e0198528. [CrossRef]

24. Huang, M.-C.; Lee, C.-L.; Ochiai, Y.; Watabe, S. Thermostability of Tropomyosins from the Fast Skeletal Muscles of Tropical Fish Species. Fish Physiol. Biochem. 2019, 45, 1189-1202. [CrossRef]

25. Huang, M.-C.; Ochiai, Y. Fish Fast Skeletal Muscle Tropomyosins Show Species-Specific Thermal Stability. Comp. Biochem. Physiol. Part B Biochem. Mol. Biol. 2005, 141, 461-471. [CrossRef] 
26. Ochiai, Y.; Ozawa, H.; Huang, M.-C.; Watabe, S. Characterization of Two Tropomyosin Isoforms from the Fast Skeletal Muscle of Bluefin Tuna Thunnus thynnusorientalis. Arch. Biochem. Biophys. 2010, 502, 96-103. [CrossRef]

27. Cai, Q.; Zhang, W.; Zhu, Q.; Chen, Q. Influence of Heat Treatment on the Structure and Core IgE-Binding Epitopes of RAra h 2.02. Food Chem. 2016, 202, 404-408. [CrossRef]

28. Li, T.; Bu, G.; Xi, G. Effects of Heat Treatment on the Antigenicity, Antigen Epitopes, and Structural Properties of $\beta$-Conglycinin. Food Chem. 2021, 346, 128962. [CrossRef]

29. Xi, J.; Yao, L.; Li, S. Identification of $\beta$-Conglycinin $\alpha^{\prime}$ Subunit Antigenic Epitopes Destroyed by Thermal Treatments. Food Res. Int. 2021, 139, 109806. [CrossRef]

30. FAO. The State of World Fisheries and Aquaculture 2020. Available online: http://www.fao.org/documents/card/en/c/ca922 9en (accessed on 18 September 2021). 